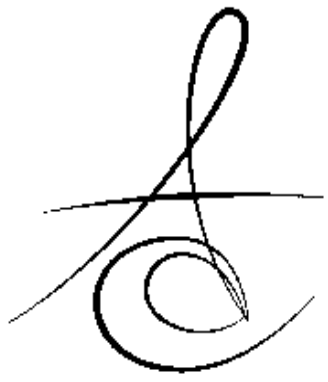

Makale Kodu/Article code: 2765

Makale Gönderilme tarihi: 04.04.2016

Kabul Tarihi: 10.05 .2016

\section{ROMATİZMAL HASTALIKLAR VE DİŞ HEKİMİ YAKLAŞIMI ${ }^{*}$}

\section{RHEUMATIC DISEASES AND DENTIST APPROACH ${ }^{*}$}

\author{
Dr. Öğr. Üyesi Selin YEŞíLTEPE* \\ Arş. Gör. Dt. İrfan SARICA**
}

öz

Romatizmal hastalıklar, klinik olarak, eklem ve periartiküler dokuların tutulumuyla seyreden kas-iskelet sistemine ait birçok bozukluğu kapsamaktadırlar. Romatizmal hastalıklarda oral mukoza belirtileri, bazı hastalıklarda tanı veya sınıflama kriterlerine girecek kadar ayrı bir öneme sahiptir. Bu hastalıkların tedavisinde kullanılan ilaçlar ve etkileşimleri, hastalıkların oral mukoza ve çene eklemlerindeki tutulumları diş hekimleri açısından önem taşımaktadır. Bu derlemede romatizmal hastalıklar ve diş hekimi yaklaşımları ile genel bilgilere yer verilmiştir.

Anahtar Kelimeler: Romatizmal hastalıklar, diş hekimliği, ağız sağlığı

\section{GİRIŞ}

Romatizmal hastalıklar, eklemleri, kasları, konnektif dokuları, eklemlerin ve kasların etrafındaki bursa ve tendonlar gibi yumuşak dokular dahil tüm kas ve iskelet sistemini etkileyen ağrılı durumlardır. Vücuttaki diğer organlar ve sistemler de etkilendiği için multisistemik hastalıklar olarak isimlendirilirler. ${ }^{1}$

Kesin olarak etiyolojileri bilinmemekle birlikte oluşum süreçlerinde immünogenetik mekanizmalara ek olarak çevresel faktörlerin rolü olduğu kabul edilmektedir.

Tanınabilen 100 'den fazla romatizmal hastalık vardır. $^{2}$ Çeşitli şekillerde sınıflandırılmaları yapılmış olan romatizmal hastalıklar, bu derlemede, artritler, konnektif doku bozuklukları, spondiloartropatiler, kristal ilişkili artropatiler, vaskülitler, endokrin ve hematolojik sistem, metabolik kemik hastalıkları ve diğer

\section{ABSTRACT}

Rheumatic diseases, clinically, cover many disorders of the musculoskeletal system which characterized by the involvement of the joints and periarticular tissues. Oral mucosal symptoms in rheumatic diseases, has a different significance enough to enter the diagnostic and classification criteria of some diseases. Drugs and interactions used in the treatment of this disease, involvement of the oral mucosa and jaw joint diseases is important for dentists. In this review it is given general information on rheumatic diseases and dental approaches.

Keywords: Rheumatic diseases, dentistry, oral health sistemik hastalıklar ile ilişkili artritler başlıkları altında anlatılmıştır.

\section{ARTRITLER}

- Romatoid Artrit (RA): En sık erişkinde görülen, kronik, sistemik, otoimmün bir hastalıktır. Birçok doku ve sistemi etkileyebilir. Primer olarak sinovial dokuları hedef alır, sinovyumun aşırı proliferasyonu etrafındaki dokuların erozyonuna yol açar. ${ }^{3}$ Hastalarda hafif bir eklem ağrısı, sabah tutukluğu ve küçük eklemlerde simetrik şişlik karakteristiktir. En sık el ve el bileği tutulur. Temporomandibular eklem tutulumu daha az sıklıkta ve genellikle geç dönemlerde görülebilir. Çiğneme kaslarında hassasiyet, hareket kısıtııı̆̆ özellikle mandibular kondil translasyon hareketinde azalma şeklinde ortaya çıkar. ${ }^{4}$ Amerikan Romatizma Derneği tarafından tanı kriterleri, 1987 yılında yenilemiştir. Bu kriterler: en az bir saat süren sabah sertliği, üçten

\footnotetext{
*Adnan Menderes Üniversitesi, Diş Hekimliği Fakültesi, Ağız, Diş ve Çene Radyolojisi AD, Aydın.

** Atatürk Üniversitesi, Diş Hekimliği Fakültesi, Ağız, Diş ve Çene Radyolojisi AD, Erzurum.

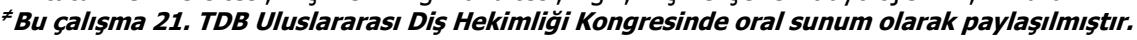


daha fazla eklem bölgesinin tutulumu, el eklemlerinin tutulumu, simetrik artrit, romatoid nodül, romatoid faktör pozitifliği, özellikle el ve bilek eklemlerinde röntgende belirlenebilen erozyonlardır. Kriterlerden en az 4 tanesinin bulunması ve hastanın yakınmalarının 6 haftadır devam ediyor olması tanı koydurucudur. ${ }^{5}$

- Juvenil Romatoid Artrit (Still's Hastalığı): 16 yaş ve daha öncesinde başlayan, sebebi bilinmeyen, nadir görülen bir rahatsızlıktır. ${ }^{6,7}$ Yetişkinlerdeki RA'ya benzetilebilir. Büyüme ve gelişmeyi bozabilir. ${ }^{8}$ Mandibular epifizin erken kapanmasına bağlı olarak mikrognati oluşabilir. Class 2 divizyon 1 tipi malokluzyona sebep olabilir. ${ }^{9}$

- Osteoartrit (OA): Dejeneratif artrit olarak da bilinen, eklem kıkırdağı ile subkondral kemikte yapım ve yıkım olayları arasındaki normal dengenin bozulması sonucu gelişen dinamik bir hastalık sürecidir. ${ }^{10}$ Primer (idiopatik) veya bilinen bir nedene bağlı sekonder olarak gelişebilir. 65 yaş üzerindeki kişilerin \% 6090 'ında OA bulgularına rastlamak mümkündür. Tüm eklem hastalıklarının en yaygını ve fiziksel yetersizliğin en sık nedenlerinden biridir. Bazı eklemler (parmaklar, kalça, diz ve omurga) daha sık tutulur. Ağrı, eklem sertliği, eklem hareket açıklığının kısıtlanması ve eklem sesleri en yaygın görülen semptomlarıdır. ${ }^{11}$

Artrit eğer mandibular kondil ve fossada destrüktif bir durum olarak karşımıza çıkarsa temporomandibular eklem (TME) osteoartriti adını alır. Eklemin artmış yüke karşı verdiği cevap olarak kabul edilen bu durumu hastalar mandibula hareketleri sırasındaki tek taraflı eklem ağrısı ile ifade eder. Ağrı gün içinde genellikle stabildir, akşama doğru artabilir. Eklem ağrısı kaynaklı kısıtlı ağız açıklığı bu durumun klinik karakteristiğidir. Osteoartrozdan farkı, ağrı ve bu nedenle sınırı ağız açıklığı olmasıdır. Krepitasyon hasta tarafından tarif edilebilir veya klinik muayene sırasında hissedilebilir. Teşhis TME radyografileri ile desteklenmelidir. Kemik değişimleri aktif olduğunda bu durum osteoartrit; değişimler sabit kalır ancak kemik morfolojisi değişmiş olarak gözlenirse bu durum osteoartroz olarak isimlendirilir. ${ }^{12}$

\section{Diş Hekimi Yaklaşımı}

Hastalar genellikle asetilsalisilik asit (ASA) ve non steroidal antiinflamatuar ilaçlar (NSAİ̇) kullanırlar. Romatoid artritte kullanılan antienflamatuar dozlar, normal analjezik ve antipiretik dozlardan fazladır. ASA, trombositlerin siklo-oksijenaz sistemini geri dönüşümsüz inhibe eder ve trombositlerin fonksiyonlarını bozar. Bunun için ASA içeren medikasyon, dental prosedür- den 7-10 gün önce durdurulmalıdır. Non steroidal antiinflamatuar (NSAİ) ilaçların, gastrointestinal toksisite, özellikle kanama ve ülser perforasyonu, trombosit fonksiyon bozuklukları ve böbrek kan akımında azalmalara neden olabileceği her zaman göz önünde bulundurulmalıdır. ${ }^{13,14}$ NSAİ ilaçların siklo-oksijenaz inhibisyonu geri dönüşümlü olduğu için çoğu diş hekimi dikkatli hemostatik protokol kullanarak müdahale etmeyi tercih eder. Eğer kanama zamanı yükselmiş ve mutlaka cerrahi tedavi gerekiyorsa, hastanın doktoruyla konsülte edilip kullandığı ilaçlara ara verilmeli ya da trombosit fonksiyonları etkilemeyen selektif COX-2 NSAİ̇'ler verilmelidir.

RA hastalarında, hastalığın sakatlıklara neden olma potansiyelini değiştirme özelliğine sahip olan hastalığı modifiye edici ilaçlar (DMARD) kullanııı. ${ }^{15} \mathrm{Bu}$ ilaçlardan metotreksat, yüksek etkinliği, kullanım kolaylığı ve etkisini süratle göstermesi açısından en çok tercih edilen ilaçların başında gelmektedir. Buna karşın hematolojik, pulmoner ve karaciğere ilişkin yan etkileri ve yüksek teratojenite potansiyeli bulunmaktadır. Bunun için ilaç kaynaklı hepatit ve pansitopeni komplikasyonu olabileceği için yakın zaman tam kan sayımı ve karaciğer fonksiyon testleri istenmelidir. ${ }^{16,17}$ Metotreksat kullanımı oral mukoza ve dilde atrofiye neden olabilir. Anti malaryal ilaçlar grubunda yer alan hidroksiklorokin ve klorokin, ayrıca altın preparatları, romatoid artrit tedavisinde kullanılan etkili ilaçlardandır. Altın preparatları çoğu hastada kemik iliği supresyonu, nefropati, stomatitis, tat değişikliği ve döküntülere neden olur. ${ }^{16}$ D-penisilamine, kullanılan ilerlemiş vakalarda bu ilaçların yan etkileri (kemik iliği supresyonu, nefropati ve otoimmün hastalıklar) göz ardı edilmemelidir. Bunun yanında D-penisilamine tat duyusunda bozukluğa ve stomatitise yol açabilir. Bir antibiyotiğin (sülfapiridin) ve bir antienflamatuar (salisilik asit) ilacın kombinasyon ürünü olan sülfasalazin, romatoid artrit tedavisinde yavaş etkili yeni bir ilaçtır. Sülfasalazin kemik iliğini baskılayabilir, bu yüzden kullanan hastalar kan sayımı yaptırmalıdır. ${ }^{18}$ Kortikosteroid kullanan hastalarda adrenal supresyon hatırlanmalı ve buna karşın önlem alınmalıdır. Bunun için de işlemler kısa tutulmalı ve stres elimine edilmelidir. Bu hastalarda enfeksiyonlara karşı eğilim artmış olduğundan bakteriyel, virütik ve fungal enfeksiyonlar gelişebilir. Bunun için bakteriyemi riskinin bulunduğu vakalarda antibiyotik proflaksisi uygulanmalıdır. Amerikan Ortopedik Cerrahlar Akademisinin (AAOS) tavsiyeleri doğrultusunda, ortopedik pin, tabaka ve çivi taşıyan, ya da eklem protezi 
olan hastalarda antibiyotik profilaksisi genellikle gerekli değildir. ${ }^{19}$ Ancak, bazı hastaların premedike edilmeleri uygun olmaktadır. Eklem protezlerinin hematojen yolla enfekte olması ihtimali olan yüksek risk grubu hastalar; immünosuprese, enflamatuar atropati, romatoid artrit, sistemik lupus eritematozus hastaları, ilaç veya radyasyon nedeniyle oluşmuş immünosupresyon durumları, insulin bağımlı (tip 1) diabet hastaları, eklem protezi yerleştirildikten sonraki ilk iki yıl, daha önce eklem protezi enfeksiyonu geçirmiş olanlar, yetersiz beslenenler ve hemofili hastaları olarak sıralanabilir.

\section{SPONDİLOARTROPATÍLER}

Spondiloartrit (SpA) grubu hastalıklar, sistemik enflamatuvar romatizmal patolojilerin çok geniş ve önemli bir alt grubunu oluşturur. Bu grubun belli başlı üyeleri; ankilozan spondilit (AS), reaktif artrit (ReA), psöriyatik artrit (PSA) ve enflamatuar bağırsak hastalıkları ile ilişkili artrit şeklinde özetlenebilir. ${ }^{20}$

Spondiloartropatilerin başlıca özellikleri; sakroiliak eklemin (sakroiliit), omurganın (spondilit), tendon bağlanma yerlerinin (entesit) ve gözün ön kamerasının (üveit) enflamasyonudur. Sakroiliit ve spondilit bu grup hastalıkların işareti olup, diğer romatizmal hastalıklarda görülmezler. Hastalarda genellikle önemli düzeyde ve bazen saatlerce sürebilen sabah sertliği ve hareketsizlik sonrası gelişen ağrı olmaktadır. Birbirleriyle çok fazla örtüşen bu grup hastalıklar, ilintili bozukluklar olarak düşünülmelidir. ${ }^{21}$

- Ankilozan Spondilit(AS): Genellikle erken evrede sakroiliak eklemlerde inflamasyona yol açan ve hastalık ilerledikçe aksiyel omurgayı da etkileyebilen, ekstraartiküler klinik bulgular gösterebilen, etiyolojisi belli olmayan, sistemik, kronik ve enflamatuvar romatizmal bir hastalıktır. ${ }^{22}$ Belde, sakroiliak eklemler üzerinde künt, kronik, özellikle sabaha karşı ve istirahat ile artan, sıcak, egzersiz ve NSAİ ilaçlar ile azalan ağrılar, hareket kısıtlanmaları en sık görülen semptomlardır. Hastalarda sabah tutukluğu mevcuttur. Düşük dereceli ateş, yorgunluk, halsizlik ve kilo kaybı gibi sistemik semptomlar görülebilir. ${ }^{23}$

- Reaktif (Reiter) Artrit: Üretrit, konjüktivit ve bazı dermatolojik sorunlar, bu hastalığa özgü klinik özelliklerdir. Bu hastalarda çukurlaşma olmadan tırnak kalınlaşması ve ağız ülserleri de görülebilmektedir. ${ }^{24}$

- Psöriyatik Artrit: Cilt ve tırnaklarda psöriazis lezyonu olan kişilerde gelişen kronik inflamatuar bir artrittir. Artrit sıklıkla asimetriktir ve bazı şekilleri distal interfalengeal eklemleri tutar. Deri hastalığı ve artrit arasında zamansal ilişki ya çok azdır ya da yoktur, biri diğerinden yıllar önce gelişebilir. ${ }^{25}$

\section{Diş Hekimi Yaklaşımı}

AS'li pek çok hastanın eklem tutulumları sebebiyle el ve bilek hareketlerini kısıtlı yapabilecekleri ve çene eklemi tutulumu olanlarda ağız açıklığında azalma olabileceği göz önüne alınmalıdır. Ağız açıklığı sınırlı hastalarda ölçü almak oldukça zordur. Özellikle hareketli bölümlü protez yapımı ve protezi hasta ağzına yerleştirmek hekime güçlük çıkarabilir. Böyle hastalarda parçalı ve katlanabilir protezler tavsiye edilir. ${ }^{26}$ Hastaların oral hijyen uygulamalarında kullandığı diş fırçasının sap kısımlarının destekleyici materyallerle hacminin artırılması veya elektrikli diş fırçasının önerilmesi faydalı olabilir. Geleneksel mekanik temizlik işlemlerinin yanı sıra irrigasyon cihazları, klorheksidinli veya florlu gargaraların kullanımı da hastaların ihtiyacı göz önüne alınarak önerilebilir. Yetersiz tükürük akışkanlığı oral kavitedeki tamponlamayı riske atar, bakteriler tarafından asit üretilmesine izin verir ve dişlerde aşınmalara sebep olur.

Psöriyatik artriti olan hastalarda fissürlü dil, coğrafik dil ve anguler cheilitis görülebilir.

Hastalarda antibiyotik profilaksisine gerek duyulup duyulmadığına hekimiyle birlikte karar verilmelidir. Kullanılan ilaçların (metotreksat, sülfasalazin, siklosporin, altın bileşikleri, retinoid tedavisi ve kolşisin) yan etkileri bilinmelidir. Kortikosteroidin adrenal supresyon yaptığı unutulmamalıdır.

\section{KONNEKTİF DOKU BOZUKLUKLARI}

- Sistemik Lupus Eritematozus (SLE): Genetik yatkınlığı olan bireylerde hormonal ve çevresel faktörlerin etkisiyle ortaya çıkan, aktivasyon ve remisyon dönemleriyle seyreden, çok sayıda sistemi tutan, kronik otoimmün bir hastalıktır. ${ }^{27}$ Ateş, kilo kaybı, güçsüzlük gibi genel semptomlar SLE'de gözlenen nonspesifik bulgulardır. Hastalığın herhangi bir döneminde, geçici süre de olsa cilt tutulumu gözlenir. Malar raş adı verilen, özellikle güneşle ortaya çıkan, yanak ve burun üzerindeki kelebek şeklinde eritemli, düz veya kabarık kırmızı döküntüler, SLE'de en sık görülen lezyonlardır. ${ }^{28}$ Ciltte kabarcık ve ülserasyon nadirdir, ancak müköz zarlarda, genellikle ağrısız, tekrarlayıcı ülserler (özellikle sert damağın ortasında sert ve yumuşak damağın birleşme yerine yakın, yanak, diş eti mukozasında ve anterior nazal septumda) sıktır. Diskoid lezyonlar düzensiz skar bırakan lezyonlardır. Oral mukozaya yerleştiğinde liken planus veya lökoplaki ile karışabilirler. 
SLE'de genellikle hafiften ağıra kadar değişen özellikte, aşındırıcı olmayan, en çok el, el bileği ve dizlerde poliartrit gözlenir. Lupus nefriti, SLE'nin en ciddi klinik bulgularındandır. ${ }^{29}$ Kardiyovasküler, pulmoner, gastrointestinal, hematolojik, vasküler, nöropsikiyatrik tutulum ve göz tutulumu gözlenebilir.

Hastalarda kortikosteroid ve immünosupresif ilaç kullanımı nedeniyle sistemik enfeksiyonlara yatkınlık olur. Bu durum göz önünde bulundurularak bu hastalarda antibiyotik profilaksisi uygulanmalıdır. Hastalar raynaud fenomeni için aspirin ve kalsiyum kanal blokerleri kullanıyor olabilirler. Bu ilaçlar etkileşim ve yan etki bakımından göz önünde bulundurulmalıdır. ${ }^{30}$

- Sjögren Sendromu (SS): Ağız, göz ve diğer müköz zarlarda kuruluk ile karakterize, kronik, sebebi bilinmeyen, otoimmün, sistemik inflamatuar bir hastalıktır. Primer ve sekonder olmak üzere iki formu vardır. Primer sjögren sendromunda (PSS); gözyaşı ve tükürük bezlerinin otoimmün hasarı ile gelişen kuru göz ve kuru ağız semptomları bulunmaktadır. Sekonder SS'de, primer SS bulgularına ek olarak, eşlik eden bağ dokusu hastalığı mevcuttur. Bunlar; en sık RA olmak üzere, SLE, Wegener, sistemik skleroz, primer biliyer skleroz gibi hastalıklardır. ${ }^{31}$ Sjögren sendromu romatoid artrit benzeri artrite sebep olabilir ve çeşitli dış salgı bezlerini ya da diğer organları etkileyebilir.

Sjögren sendromunda tükürük salınımı eksikliği bir takım oral problemlere yol açar. Azalmış tükürük akımı nedeniyle boğaza kadar uzanan yanma hissi, konuşmada ve özellikle kuru gıdaların çiğnenmesi ve yutulmasında güçlük vardır. Hastalar kıvamı artmış tükürükten ve dilde acı-yanma hissi ile tat bozukluğundan yakınırlar. Tükürük miktarlarının azalması ve antibakteriyel etkilerinin kaybolması, oral florada ve $\mathrm{pH}^{\prime}$ da değişiklikler nedeniyle diş çürümeleri hızlanır. ${ }^{32}$ Hastaların ağız muayenesinde oral mukozada atrofi, fissürleşme ve ülserasyon gözlenebilir, ince ve parşömen benzeri görünüm saptanır. Dudaklarda kuruluk ve köşelerinde çatlaklar ve kandidiyazis dikkati çekebilir, nadiren protezlerin ağıza eskisi kadar uymaması gibi şikâyetler olabilir. ${ }^{33}$ Papillaların atrofisinden dolayı, dil kaldırım taşı görünümündedir. Primer Sjögrenli hastaların \% 60'ında parotislerde unilateral veya bilateral olarak şişme göze çarpar. Bez genelde ağrısız ve lastik kıvamındadır, bazen ateş ve duyarlılık olabilir. Hastalarda tükürük akıcılığının azalması ile kanallarda taş oluşma riski artmıştır. Parotis infeksiyonu ve apsesi oluşabilir.

SS'de tedavi semptomlara ve hayatın daha konforlu yaşanmasına yöneliktir. Oral mukozanın nemlili- ğini devam ettirmek, çürük ve kandidal enfeksiyonlardan korunmak için tükürük stimülasyon ve destekleme tedavileri uygulanır. Tükürük yerine geçen topikal ajanlar uygulanabilir, su, şekersiz sıvı gıdaların alımı arttırılabilir. Şekersiz drajelerle tükürük akımı stimüle edilir. Tükürük salgısını artırmak için; Bromhexine, Anetholetrithionin, Pilocarpine, Cevimeline gibi sistemik ilaçlar kullanılabilir. ${ }^{34}$ Çürüklerden korunmak titiz bir ağız bakımı ve düzenli diş hekimi kontrolleri yapılmalıdır. Hastaların kullanıyor olabileceği hidroksiklorokin, metotreksat, azatioprin, siklosporin ve korti- kosteroidler göz önünde bulundurulmalıdır.

- Sistemik Skleroz (Skleroderma): Cilt, eklem ve iç organlarda yaygın fibrozis (aşırı kollojen üretimi), dejeneratif değişiklikler ve vasküler anormallikler ile karakterize, sebebi bilinmeyen, kronik bir hastalıktır. Sık görülen semptomları arasında raynaud fenomeni, poliartralji, şişlik ve sonuçta ciltte gerginleşme ve parmaklarda kontraktürler sayılabilir.

Fasiyal ve mukozal fibrozis nedeniyle yüz gergin, maske gibi görünür, mikrostomiya gelişir. Hastanın ağzı büzülmüş kese gibi karakteristik bir görünüm arz eder. Mikrostomiya bu hastalarda ağız açıklığını $\% 70$ sınırlar. ${ }^{35}$ Bunun sonucu olarak oral hijyen ve hareketli bölümlü protezlerin yapımı sınırlı erişim, mukobukkal kıvrımların sığlaşması veya yok olması nedeniyle oldukça güçleşir. Tükürük ve gözyaşı bezlerinin fibroze olması sonucu ağız ve göz kuruluğu gelişir. Progresif (ilerleyici) sistemik sklerozun klasik dental radyografik bulguları periodontal ligamentte ve periodontal ligament aralığında kalınlaşma olduğunu göstermiştir. Ortopantomografta mandibula açısında bir düzleşme, "balina kuyruğu"na benzer bir görüntü izlenir. Nadiren mandibular rezorpsiyona bağlı patolojik mandibula kırığı oluşabilir. ${ }^{36}$ Çene kemiklerinde özellikle angulus mandibula etrafında kemik rezorpsiyonları radyolojik olarak çok iyi değerlendirilmelidir.

Hastalarda gelişebilecek ağız kuruluğuna karşı yapay tükürük preparatları; çürük oluşumunu önlemede de flor uygulaması düşünülebilir. Diffüz sklerodermada mutlaka konsültasyon istenmelidir.

\section{KRİSTAL İLİŞKİLİ ARTROPATİLER (GUT)}

Gut, özellikle orta yaşlı erkeklerde görülen, epizodik akut ve kronik artrit atakları ile seyreden, monosodyum ürat (MSÜ) kristallerinin dokuda, özellikle böbrek ve bağ dokusunda birikmesi ile karakterize metabolik bir hastalıktır. ${ }^{37}$ Akut artrit başlangıçta monoartikülerdir. Sıklıkla ayak başparmağı, ayak bileği

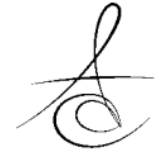


ya da ayağın diğer eklemlerini etkiler. Yaş ve cinsiyet ürik asit ve gut prevalansını etkileyen değiştirilemez önemli iki risk faktörüdür. Uzun yıllar serum ürik asit yüksekliği, pürinden zengin gıda alımı (kırmızı et, deniz mahsülleri), obezite ve alkol gut hastalığı için diğer risk faktörleridir. ${ }^{38}$

Akut artrit atağının tedavisinde inflamasyonun baskılanması hedeflenir. Bu amaçla NSAİİler, kolşisin ve hastanın yaşına bağlı olarak glukokortikoidler kullanılır. ASA bileşiklerinin, serum ürik asit seviyesini yükselterek akut alevlenmelere neden olabileceği göz önünde bulundurularak gut hastalarında reçete edilmemelidir.

\section{SİSTEMİK BOZUKLUKLARIN ROMATİZMAL} BELİRTÍLERİ

Sistemik bozukluklar kas-iskelet sistemine ait belirtilerle ortaya çıkabildiklerinden, bu belirtilerin tanınmasıyla erken tanı ve tedavi olanağı doğabilir.

- Endokrin Hastalıklar: Hemen hemen bütün endokrin hastalıklar eklemlerde ve periartiküler dokularda bazı belirti ve bulgulara neden olabilir. Bu nedenle endokrin hastalıkların romatizmal bulguları klinikte sıkça rastlanan sorunlardır. ${ }^{39}$ Muskülotendinoz, kemik veya eklem anomalileri muhtemelen metabolik dengesizlik sürecini takiben oluşur ve ilgili dengenin sağlanması ile romatizmal hastalıkların klinik belirtilerinde azalma veya düzelme olabilir.

- Hematolojik Hastalıklar: Hemofili (faktör VIII ve IX eksikliği), hemoglobinopatiler (sickle cell anemi ve B talasemi), multiple myelom ve amiloidoz gibi hematolojik bozukluklar kanama problemlerine ek olarak romatizmal semptomlar sunabilirler.

Hipertrofik osteoartropati, lösemi, lenfoma, karsinomatöz poliartrit gibi maligniteyle ilişkili hastalıklar, whipple hastalığı, hemakromatozis, primer biliyer siroz gibi gastrointestinal hastalıklarda da romatizmal semptomlar mevcuttur. ${ }^{40}$

\section{METABOLİK KEMİK HASTALIKLARI (OSTEOPOROZ)}

Günümüzde osteoporoz, kemik gücünde azalma sonucunda kırıklara yatkınlığın arttığı sistemik bir iskelet sistemi hastalığı olarak tanımlanmaktadır. Kemik yoğunluğu ve kemik kalitesi, kemik gücünü belirleyen en önemli parametrelerdir. ${ }^{41}$

\section{Osteoporozun Etiyolojik Sinıflaması}

-Birincil Osteoporoz (Primer osteoporoz): Osteoporozun \%95'inden fazlası primerdir. İdiyopatik, postmenopozal (Tip I), senil osteoporoz (Tip II) olmak üzere 3 tipi vardır.

-İkincil Osteoporoz (Sekonder osteoporoz): Osteoporoz olgularının \% 5'ini oluşturur. Endokrin, gastrointestinal sistem, bağ dokusu hastalıkları, malign hastalıklar, ilaçlar, diyet, kronik böbrek hastalığı, $\mathrm{KOAH}$, alkolizm, sigara, skorbüt gibi durumlar sekonder osteoporoze neden olabilir. ${ }^{42}$

Mandibular kemik kütlesinin osteoporozla ilişkisi

Kemik kütlesi için yapılan ölçümlerde alveolar kemik yoğunluğundaki azalma osteoporoz ile uyumlu bulunmuştur. Osteoporozlularda çeneler, kemik kütlesindeki azalmanın önemli bir göstergesidir. Osteoporoz ve oral kemik kaybı arasındaki ilişki ilk olarak 1960'larda açıklanmıştır. ${ }^{43}$

Osteoporotik çene kemikleri ince, belirsiz trabeküllü olup, korteks incelmiştir. Ayrıca senil ve postmenapozal osteoporozda, lamina dura incelmiş olarak gözlenir. Alt çenede de etkili olan osteoporotik kemik kaybı ile hastalar, yeme-içme, hatta konuşma esnasında bile çene kırığıyla karşılaşabilirler. ${ }^{44}$

\section{Osteoporoz tedavisinde kullanılan bifosfanatlar ve diş hekimliği}

Bifosfonatlar kemik rezorbsiyonunun güçlü inhibitörleridir. Osteoporoz tedavisinde veya kanserle ilişkili durumların tedavisinde oral yolla veya intravenöz olarak yaygın olarak kullanılan ilaçlardır. Bifosfonata bağlı osteonekroz (BON) ender olarak görülen ancak ciddi, genellikle geri dönüşü olmayan bir durumdur. ${ }^{45}$ Osteonekroz diş çekimi gibi invaziv dental işlemler sonrasında oluşabildiği gibi bu ilaçları alan hastalarda kendiliğinden de oluşabilir. Bifosfonat kullanan hastalarda periost ve kemiği ilgilendiren invaziv işlemleri gerçekleştirmeden önce osteonekroz gelişme riski konusunda hastaya detaylı bilgi verilmelidir. Osteonekroz vakalarının genellikle dental işlemden sonraki 2 ay içinde ortaya çıkması sebebiyle her cerrahi işlem arasında 2 aylık bekleme ve takip süresi bırakılması önerilmektedir. Diş çekimi yerine endodontik tedavi, implant yerine köprü veya parsiyel protez seçenekleri düşünülmelidir. Diş çekimi veya kemiği ilgilendiren işlemler mümkün olduğu kadar atravmatik olmalıdır. Antibiyotik kullanımına hastanın kendine özgü durumu ve risk faktörleri (bifosfonatların uzun süredir kullanımı, ileri yaş, aynı zamanda östrojen ve glukokortikoid kullanımı) dikkate alınarak karar verilebilir. ${ }^{46}$ 


\section{VASKÜLİTLR}

- Behçet Hastalığı (BH): İlk olarak 1937 yılında Prof. Dr. Hulusi Behçet tarafından rekürrent aftöz stomatit, genital ülserasyon ve üveitle karakterize bir sendrom olarak tanımlanmıştır ancak sonradan hastalığın bir sendrom olmadığı ve artiküler, vasküler, gastrointestinal ve santral sinir sistemi gibi çok çeşitli sistem tutulumlarının izlendiği, kronik, multisistemik bir hastalık olduğu anlaşılmıştır. Rekürrent aftöz ülserler Behçet hastalığının olmazsa olmaz lezyonlarıdır. Olguların \%75-90'ında hastalığın ilk bulgusu olarak ortaya çıkmakta ve hastalığın sistemik semptomları ortaya çıkana kadar yıllarca tek bulgu olarak kalabilmektedir. Minör, majör ve herpetiform aftlar olmak üzere 3 değişik şekilde görülürler.

Yılda en az üç kez tekrarlama özelliği gösteren oral ülserler $\mathrm{BH}$ için olmazsa olmaz bir tanı kriteridir ${ }^{47}$ Behçet hastalığınd a gözlenen oral ülserler daha ağrılı ve daha sık tekrarlama eğiliminde olmalarına rağmen morfoloji ve lokalizasyon bakımından rekürrent aftöz stomatitten ayırt edilmeleri çok zordur . Ancak klinik olarak, daha fazla sayıda olmaları (aynı anda 6 ve daha fazla), lezyon çaplarının birbirinden farklı olması , lezyon çevresinde belirgin eritemli halka gözlenmesi , yumuşak damak ve orofarenks tutulumunun olması $\mathrm{BH}$ oral ülserlerinin RAS ülserlerinden ayırımında önemli kriterlerdir. Genital ülserasyonlar Behçet hastalarında \%74-97 oranında bulunur. Oral aftlardan daha derindirler ve skatris bırakarak iyileşirler. ${ }^{48}$ Behçet hastalarında en sık gözlenen deri lezyonları eritema nodozum benzeri lezyonlar, papülopüstüler lezyonlar, yüzeyel tromboflebit ve paterji fenomenidir. Behçet hastalığında gözlenen sistemik tutulumların başında göz tutulumu gelmektedir. Olguların \%28-79' unda görülmekte olup başlıca ön üveit, arka üveit ve retinal vaskülit şeklinde görülür. ${ }^{49}$ Oral ülserlerin neden olduğu ağrı kişinin daha yumuşak ve karbonhidrat ağırlıklı bir beslenme düzenine dönmesine neden olmaktadır.

Bu durum kişi de biofilm olarak tanımlanan dental plak oluşumunu kolaylaştırmaktadır. Lokal travmalar yeni mukozal lezyonların gelişimini tetikleyebilir. Dental girişimler sonrasında, erken dönemde hastalığın alevlenebileceği konusunda hasta ve diş hekimi bilgilendirilmelidir. Bu tedaviler mümkünse, hastalığın kontrol altına alındığı dönemde yapılmalıdır. ${ }^{50}$ Dental tedavi sırasında antibiyotik kullanımının hastalığın alevlenmesinin önlenmesi konusundaki etkinliği bilinmemektedir. Oral florayı baskılayabilecek antibiyotikler işlem öncesinde kısa süreli kullanılabilir. Sistemik kortikosteroid veya immünosupresif kullanan hastalarda, dental girişimler sonrasında iyileşme olumsuz etkilenebilir ve enfeksiyon riski artabilir.

- Wegener Granülomatozis: Etiyolojisi bilinmeyen, küçük ve orta çap arterleri tutan, başlıca üst ve alt solunum yollarını ve böbreği etkileyen, sistemik nekrotizan granülamatöz bir vaskülit tipidir. ${ }^{51}$ Diş eti inflamasyonu lokal veya genel hiperplaziye neden olabilir. Bu lezyonlardan tanı amaçlı biyopsi alınabilir. Hastaların kortikosteroid, siklofosfamid veya metotreksat gibi immünosupresif ajan tedavileri alabilecekleri unutulmamalıdır.

- Kawasaki Hastalığı: Etiyolojisi bilinmeyen, özellikle küçük ve orta boy arterleri tutan, çoğunlukla beş yaşın altındaki çocukları etkileyen, çocukluk çağının en sık görülen sistemik vaskülitlerinden biridir. Ateş, deri döküntüleri, konjüktivit, enantem (boğaz ve ağız mukozasında kızarıklık), ellerde ve ayaklarda şişme, büyümüş lenf nodlarıyla karakterizedir. ${ }^{52}$ Ağız değişiklikleri, parlak kırmızı çatlamış dudaklar, genellikle "çilek dili" olarak adlandırılan kırmızı dil ve boğazda kızarıklık bulgularını içerir. Birkaç yıl sonra gelişen koroner arter anevrizması gibi komplikasyonları bildirilmiştir. Kalpte perikardit, miyokardit ve endokardit görülebilir.

\section{DİĞER SİSTEMİK HASTALIKLAR}

- Sarkoidozis: Nedeni bilinmeyen, sıklıkla genç erişkinlerde görülen, akciğerlerde nonkazeifiye granülomlar, hiler lenfadenopati, pulmoner infiltrasyon, cilt ve göz lezyonları ile ortaya çıkan, solunum sistemi belirtileri yaygın olmakla birlikte, kalp, dalak, böbrek ve gözler gibi birçok organı etkileyen sistemik, granülamatöz bir hastalıktır. Nefes darlığı, öksürük, göğüs ağrısı ya da göğüste sıkışma hissi hastaların 1/3' ünde bulunur ve en sık görülen üç semptomdur. Cilt tutulumu \%20-35 oranında görülür. Lezyonlar, histopatolojik olarak sarkoid granülomların gösterilebildiği spesifik deri lezyonları (lupus pernio vs.) ve deride reaktif değişiklikler nedeniyle ortaya çıkan non-spesifik deri lezyonları (eritema nodosum, iktiyoz, eritema muliforme gibi) olmak üzere kabaca ikiye ayrılır. Spesifik cilt lezyonlarından olan lupus pernio, kronik sarkoidozda görülür; burundan başlayarak yanak, çene ve kulak memelerine doğru genişleyebilen morumsu papül veya plaklardır. ${ }^{53}$ Parotisin tek ya da çift taraflı ağrılı büyümesi hastaların yaklaşık \% $6^{\prime}$ sında ortaya çıkar ve bunların \% 40’ kendiliğinden sınırlanır. Bazı vakalarda başlangıç belirtisi olarak gözyaşı ve tükürük 
bezlerinde şişme vardır. Şayet parotis bezinde şişlik, kserostomia, üveit ve fasial sinir felci bir aradaysa Heerfordt sendromundan bahsedilebilir. Tedavi yaklaşımlarında farklılıklar olmasına rağmen tedavi endikasyonu olan hastalarda steroidler, tedavinin temelini oluşturur. ${ }^{54}$ Hastaların kullandığı ilaçlar ve etkileri göz önünde bulundurulmalıdır.

- Akut Romatizmal Ateş (Romatizmal Kalp Hastalığı): A grubu beta hemolitik streptokokların neden olduğu akut faringeal infeksiyona gecikmiş bir tepki sonucu gelişen; kalp, eklemler, santral sinir siste$\mathrm{mi}$, deri ve derialtı dokuları tutan sistemik inflamatuar bir hastalıktır. ${ }^{55}$ En sık 5-15 yaş arlığında görülür. Akut romatizmal ateş infeksiyondan belli bir süre (yaklaşık 3 hafta) sonra artrit, kardit, subkütan nodüller, eritema marginatum ve Sydenham koreası ile ortaya çıkabilir. Streptokokkal farenjit geçiren her bireyde akut romatizmal ateş gelişmemektedir. Tanıda Modifiye Jones Kriterleri dikkate alınır. Major kriterler; kardit, poliartrit, korea, eritema marginatum, deri altı nodüller, minör kriterler ise klinik olarak ateş, artralji, laboratuvar bulgusu olarak akut faz reaktanlarında artış ve EKG'de PR mesafesinin uzamasıdır. Tanıda 2 major veya 1 major+2 minör kriterin varlığı yeterlidir. ${ }^{56}$ Anamnezinde romatizmal ateş episodu bulunan hastalarda sadece kardit ve kapak defekti olanlarda gerekli tedaviler öncesi profilaktik amaçlı antibiyotik verilmelidir. Tedavi öncesinde hastanın ağzını antiseptik gargaralar ile çalkalaması sağlanır. Bu hastalar aspirin kullanıyor olabilirler. Bu durumda, cerrahi uygulamalardan önce aspirin kesilmeli ve uygulama öncesi kanama zamanı ölçülmelidir. Kalpte bir patoloji varsa provoke etmemek için uygulanacak lokal anestezik adrenalinsiz olmalıdır. Miyokardit tehlikesi nedeni ile genel anesteziden kaçınııır.

- Aile Ailesel Akdeniz Ateşi (FMF): Karın, göğüs ve eklem ağrısı ile şşşliğinin eşlik ettiği, tekrarlayan ateş nöbetleri ile karakterize genetik bir hastalıktır. Tanıda Tel Hashomer Kriterleri kullanııır. Majör kriterler; ateşle birlikte olan peritonit, sinovit ve plörit atakları, predispozan bir hastalık olmaksızın gelişen amiloid-assosiye (AA) tipi amiloidoz, kolşisine alınan iyi yanıt, minör kriterler ise; tekrarlayan ateş atakları, erizipel benzeri eritem, birinci derece akrabada FMF varlığıdır. 2 majör veya 1 majör ve 2 minör kriterin olması kesin tanı koydurur. 1 majör ve 1 minör kriterin olması muhtemel FMF olarak değerlendirilir. ${ }^{57}$

Hastalı̆ın istenmeyen en önemli komplikas- yonu amiloidozdur. Amiloid, suda çözülmeyen bir proteindir ve Ailesel Akdeniz Ateşi sırasında yapımı artar. Kanı bu proteinlerden temizlemeye çalışan böbrekler, bunu başaramaz ve biriken amiloid, böbreğin çalışmasını bozar, hastaların \%35'inde yüksek tansiyona sebep olur ve böbrek yetmezliği gelişiri. ${ }^{58}$ En tipik cilt bulgusu, genellikle diz ile ayak bileği arasında, ayak sırtında keskin kenarlı, sıcak, hassas ve şiş kırmızı plaklar ile kendini gösterir.

Böbrek yetmezliği anamnezi alınan hastalarda trombosit fonksiyon bozukluğu görülebilir, sivı tutulumu sebebiyle sekonder hipertansiyon görülebilir. Lokal anestezi vazokonstüktörsüz seçilmelidir. Kolşisin, atakların önlenmesinde ve amiloid oluşumunu engellemede kullanııır. Kolşisinle etkileşen NSAI verildiğinde bu ilaçlar lökopeni, trombositopeni ve kemik iliği depresyonu riskini artırılar. Eritromisin ve klaritromisin kolşisin ile etkileşir ve kolşisin toksisitesini artıır.

\section{SONUÇ}

Romatizmal hastalıkların multisistemik hastalıklar grubunda olduğu göz ardı edilmemelidir. Diş hekimi olarak hastalıkların oral ve maksillofasiyal bölgedeki etkileri üzerine bilgi sahibi olunmall, hastalıkların tedavisinde kullanılan ilaçların etkileri yapılacak her türlü dental yaklaşımda göz önünde bulundurulmalıdır.

Selin Yeşiltepe: ORCID ID: 0000-0002-6857-1411

Özkan Miloğlu: ORCID ID: 0000-0002-3826-8606

İrfan Sarıca: ORCID ID: 0000-0003-1038-8275

Kübra Törenek Ağırman: ORCID ID: 0000-0001-72003436

\section{KAYNAKLAR}

1. Arend WP, Lawry GV. Appoach to the patient with musculoskeletal disease. In: Goldman L, Schafer AI, editors. Goldman's Cecil Medicine. $24^{\text {th }}$ ed. Philadelphia, Saunders, 2012.1648-51.

2. Nurşen D. Romatizmal Hastalıkların Tanımı ve Sınıflandırıması. Türkiye Klinikleri J Immunol Rheumatol 2002;2:3-5.

3. Grassi W, De Angelis R, Lamanna G, Cervini C. The clinical features of rheumatoid arthritis. Eur J Radiol 1998;27 Suppl 1:18-24.

4. Atsu SS, Ayhan-Ardic F. Temporomandibular disorders seen in rheumatology practices: A review. Rheumatol Int 2006;26:781-7.

5. Yazıcı Y, Erkan D. Romatizmal Hastalıklar Tedavi El 
Kitabı. Ankara, MD Yayıncılık, 2003: 53-64.

6. Petty RE, Cassidy JT. Textbook of Pediatric Rheumatology. $5^{\text {th }}$ ed. Philadelphia, Elsevier Saunders Company, 2005;206-341.

7. Kasapçopur Ö, Özdoğan H. Jüvenil İdyopatik Artrit. Klinik Gelişim Dergisi 2006;19:7-22.

8. Petty R, Southwood TR. Classification of childhood arthritis. Pediatric Rheumatology 1998; 25:186970.

9. Ronchezel MV, Hilario MO, Goldenberg J, Lederman HM, Faltin K, Jr, de Azevedo MF, Naspitz CK. Temporomandibular joint and mandibular growth alterations in patients with juvenile rheumatoid arthritis. J Rheumatol 1995;22:1956-61.

10. Aydın AT. Diz cerrahisi. Ankara, Yeni Fersa Matbaacllık, 1999:5-19.

11. Aydın R. Dejeneratif Romatizmal Hastalıklar. İstanbul, Nobel Tıp Kitabevleri, 2000:331-41.

12. Okeson JP. Management of temporomandibular disorders and occlusion. $6^{\text {th }}$ ed. St Louis, MosbyYear Book Inc, 2008:8-15.

13. Brooks PM, Day RO. Nonsteroidal antiinflammatory drugs--differences and similarities. N Engl J Med 1991;324:1716-25.

14. Vane JR. Introduction: mechanism of action of NSAIDs. Br J Rheumatol 1996;35:11-3.

15. Kayaalp S. O. Romatoid Artrite Karşı Kullanılan Özel Antiinflamatuvar İlaçlar: Narkotik Olmayan Analjezikler (Non Steroid Antiinflamatuvar İlaçlar). Tıbbi Farmakoloji, Ankara, Feryal Matbaacılık, 1992:2081-2.

16. Conaghan PG, Brooks P. Disease-modifying antirheumatic drugs, including methotrexate, gold, antimalarials, and D-penicillamine. Curr Opin Rheumatol 1995;7:167-73.

17. McCune WJ, Vallance DK, Lynch JP. $3^{\text {rd. }}$ Immunosuppressive drug therapy. Curr Opin Rheumatol 1994;6:262-72.

18. Day O R. Kelley's Textbook of Rheumatology. $6^{\text {th }}$ ed. Philadelphia, WB Saunders Com, 2001:853-7.

19. Advisory statement. Antibiotic prophylaxis for dental patients with total joint replacements. American Dental Association; American Academy of Orthopaedic Surgeons. J Am Dent Assoc 1997;128:1004-8.

20. Healy PJ, Helliwell PS. Classification of the spondyloarthropathies. Curr Opin Rheumatol 2005; 17: 395-9.
21. Khan MA. An overview of clinical spectrum and heterogeneity of spondyloarthropathies. Rheum Dis Clin North Am 1992;18:1-10.

22. Cooksey R, Brophy S, Gravenor MB, Brooks CJ, Burrows $C L$, Siebert $S$. Frequency and characteristics of disease flares in ankylosing spondylitis. Rheumatology (Oxford) 2010;49:929-32.

23. Braun J, Sieper J. Ankylosing spondylitis. Lancet 2007; 369: 1379-90.

24. Amor B. Reiter's syndrome. Diagnosis and clinical features. Rheum Dis Clin North Am 1998;24:67795.

25. Moll JM, Wright V. Psoriatic arthritis. Semin Arthritis Rheum 1973;3:55-78.

26. Conroy B, Reitzik M. Prosthetic restoration in microstomia. J Prosthet Dent 1971;26:324-7.

27. Oksel F. Klinik Romatoloji El Kitabı. İzmir, İzmir Güven Kitabevi, 2003:237-65.

28. Edworty SM. Kelley's Textbook of Rheumatology. $7^{\text {th }}$ ed. USA, Elsevier Saunders, 2005:1201-3.

29. Hahn BH. Harrison's Principles of İnternal Medicine. $16^{\text {th }}$ ed. London, McGraw-Hill, 2005:1960-8.

30. Hahn BH. Kelley's Textbook of Rheumatology. $7^{\text {th }}$ ed. USA, Elsevier Saunders, 2005:1225-47.

31. Vitali $C$, Bombardieri $S$, Jonsson R, Moutsopoulos $\mathrm{HM}$, Alexander EL, Carsons SE, et al. Classification criteria for Sjogren's syndrome: a revised version of the European criteria proposed by the American-European Consensus Group. Ann Rheum Dis 2002;61:554-8.

32. Pedersen AM, Bardow A, Nauntofte B. Salivary changes and dental caries as potential oral markers of autoimmune salivary gland dysfunction in primary Sjogren's syndrome. BMC Clin Pathol 2005;5:4.

33. Hamburger J. Sjogren's syndrome as seen by an oral physician. Scand J Rheumatol Suppl 2001;11534-8.

34. Samarawickrama DY. Saliva substitutes: how effective and safe are they? Oral Dis 2002;8:177-9.

35. Neville BW, Damm DD, Allen CM, Bouquot JE. Oral and maxillofacial pathology. $2^{\text {nd }}$ ed. Philadelphia, W.B. Saunders Co, 2002:137.

36. Albilia JB, Lam DK, Blanas N, Clokie CM, Sandor GK. Small mouths .. Big problems? A review of

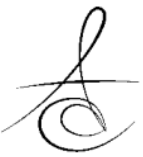


scleroderma and its oral health implications. J Can Dent Assoc 2007;73:831-6.

37. Braunwald E, Fauci A, Kasper D, Hauser S, Longo Dan L, Jameson Larry J. Harrison iç hastalıkları prensipleri. İstanbul, Nobel Kitabevi, 2004:19792018.

38. Saag KG, Choi H. Epidemiology, risk factors, and lifestyle modifications for gout. Arthritis Res Ther 2006;8 Suppl 1:2.

39. Liote F, Orcel P. Osteoarticular disorders of endocrine origin. Baillieres Best Pract Res Clin Rheumatol 2000;14:251-76.

40. Ball EV. Systemic diseases in which arthritis is a feature. In Goldman L, Bennett JC(eds): Cecil Textbook of Medicine. 21st ed. Philadelphia, WB Saunders, 2000:1556-8.

41. Osteoporosis prevention, diagnosis, and therapy. JAMA 2001;285:785-95.

42. Göksoy T. Osteoporozda Tanı ve Tedavi. İstanbul, 2000.

43. Assessment of fracture risk and its application to screening for postmenopausal osteoporosis. Report of a WHO Study Group. World Health Organ Tech Rep Ser 1994;8431:129.

44. Albright F, Smith PH, AM R. Postmenopausal osteoporosis: Its clinical features. J Am Med Assoc 1941;1162465-74.

45. Hoff $A O$, Toth $B B$, Altundag $K$, Johnson MM, Warneke $\mathrm{CL}, \mathrm{Hu} \mathrm{M}$, et al. Frequency and risk factors associated with osteonecrosis of the jaw in cancer patients treated with intravenous bisphosphonates. J Bone Miner Res 2008;23:826-36.

46. Ruggiero SL, Dodson TB, Assael LA, Landesberg R, Marx RE, Mehrotra B. American Association of Oral and Maxillofacial Surgeons position paper on bisphosphonate-related osteonecrosis of the jaw 2009 update. Aust Endod J 2009;35:119-30.

47. Mucocutaneous lesions of Behçet's disease. TURKDERM 2003;37:92-9.

48. Ghate JV, Jorizzo JL. Behcet's disease and complex aphthosis. J Am Acad Dermatol 1999;40:1-18.

49. Yurdakul S, Tüzün Y, Mat MC, Özyazgan Y, H. Y. Dermatoloji. 2.Baskı. İstanbul, Nobel Tıp Kitabevleri, 1994:393-9.

50. Mumcu G, Ergun T, Inanc N, Fresko I, Atalay T, Hayran O, Direskeneli H. Oral health is impaired in Behcet's disease and is associated with disease severity. Rheumatology (Oxford) 2004;43:1028-33.
51. Leavitt RY, Fauci AS, Bloch DA, Michel BA, Hunder GG, Arend WP, Calabrese LH, Fries JF, Lie JT, Lightfoot RW, Jr., et al. The American College of Rheumatology 1990 criteria for the classification of Wegener's granulomatosis. Arthritis Rheum 1990;33: 1101-7.

52. Cimaz R, Falcini F. An update on Kawasaki disease. Autoimmun Rev 2003;2:258-63.

53. Fraser GF. Diagnosis of Disease of the Chest,. $4^{\text {th }}$ ed. Philadelphia; W.B.Saunders Company, 1999;3:1533-83.

54. Statement on sarcoidosis. Joint Statement of the American Thoracic Society (ATS), the European Respiratory Society (ERS) and the World Association of Sarcoidosis and Other Granulomatous Disorders (WASOG) adopted by the ATS Board of Directors and by the ERS Executive Committee, February 1999. Am J Respir Crit Care Med 1999;160:736-55.

55. Carapetis JR, McDonald M, Wilson NJ. Acute rheumatic fever. Lancet 2005;366:155-68.

56. Guidelines for the diagnosis of rheumatic fever. Jones Criteria, 1992 update. Special Writing Group of the Committee on Rheumatic Fever, Endocarditis, and Kawasaki Disease of the Council on Cardiovascular Disease in the Young of the American Heart Association. JAMA 1992;268:206973.

57. Doğan DA. Çocukluk çağı Ailevi Akdeniz Ateşi hastalarında klinik ve epidemiyolojik özelliklerin belirlenmesi ve bu özelliklerle sık görülen mutasyonlar arasındaki ilişkilerin araştırılması. Bilim uzmanlığı tezi, İstanbul Üniversitesi Tıp Fak, İstanbul, 2007.

58. Yılmaz S. Ailesel Akdeniz Ateşi'nde böbrek tutulumu. İstanbul Tıp Der 2009;72:71-4.

\author{
Yazışma Adresi \\ Dr. Özkan MİLOĞLU \\ Atatürk Üniversitesi, \\ Diş Hekimliği Fakültesi, \\ Ağız, Diş ve Çene Radyolojisi A.D., \\ Erzurum, Türkiye \\ TIf: +90 4422311778 \\ Faks: +90 4422360945 \\ e-mail: omiloglu@hotmail.com
}

